\title{
Development of industry in Far East of Russia based on use of innovative investment attraction practice
}

\author{
Denis B. Solovev ${ }^{1, *}$, and Alena E. Merkusheva ${ }^{2}$ \\ ${ }^{1}$ Far Eastern Federal University (FEFU), Engineering school, 690018 Russky Island, Russia \\ ${ }^{2}$ Student in Far Eastern Federal University (FEFU), Engineering school, 690018 Russky Island, Russia
}

\begin{abstract}
The article considers the issues relevant at the present stage of economic development of the Far East of the Russian Federation. One of instruments of this economic development of the region is forming the territories of the advancing development which can be considered as one of the possible ways of interaction of industrial enterprises of the subjects of the Far Eastern Federal District with partners from the Asia-Pacific states. The features of the territories of the advancing development, the criteria for classification of the subjects of the Far East as the territories of the advancing development, and the main preferences for the residents of these territories are noted. The algorithms for the estimation of prospects of the activities of the territories of the advancing development are also given in the article. Based on the conducted theoretical researches, the criteria for evaluation of the efficiency of activities of the territories of the advancing development are determined. Based on the analysis of the criteria, a mathematical model for the estimation of efficiency of advancing development territories activities was developed, which clearly demonstrated that in the current economic environment the optimum quantity of the territories of the advancing development in the Far East, securing the maximum performance indicator of their activities, is 8 .
\end{abstract}

\section{Ways of innovative economic development of the Far East of Russia}

The Asia-Pacific Region (APR) is one of the most dynamically developing regions of the world [1]. The Russian Federation, owing to the geographical location, also treats this region. In connection with the difficult geoeconomic country situation, which developed in 2014, activization and building-up of a cooperation with Asia-Pacific countries is profitable and natural to Russia.

The Far Eastern Federal District, considering its geographical provisions, becomes the leading platform of interaction of the Russian Federation with AsiaPacific countries. It should be noted the developed unique situation: The Far East takes only the 6th place from 8 possible, proceeding from analysis results of the main socio-economic indexes [2]. In addition to lagging of the region on the main socio-economic indexes from other federal districts of Russia, it has a small indicator of an index of innovative development of the federal district, in comparison with other federal districts [3]. The index of innovative development of territorial subjects of the Russian Federation measures achievements of regions in the field of development, implementations and development of innovations; includes indicators of such primary groups as social and economic conditions of innovative activities, scientific and technical potential, innovative activities, quality of innovative policy [3].
For strengthening of innovative development of the Far East, the Government of the Russian Federation together with the Ministry of the Russian Federation of development of the Far East (the Ministry for the Development of the Russian Far East) with the assistance of scientists was developed and adopted the Federal law "About the Territories of the Advancing Social and Economic Development in the Russian Federation" [4]. This Federal law provides requirements to creation of the Territories of the Advancing Development (TAD), financing of creation of infrastructure, the existence termination, management, features of regulation of the separate relations in the territories of the advancing development [5].

During project development of the Law, the Ministry for the Development of the Russian Far East analysed international experience of creation of TORAHS in Asia-Pacific countries based on which were marked out the main criteria by which the separate territories of territorial subjects of the Russian Federation located in the Far East can be carried to the territories of the advancing development.

The main criterion is demand of the investor for placement of investment projects in the territory of the advancing development, to additional criteria refer:

1) location;

2) technical characteristics of the parcels of land; 
3) availability (proximity) of transport and engineering infrastructure;

4) characteristics of engineering networks and objects of engineering infrastructure;

5) cost of creation of transport and engineering infrastructure;

6) availability or proximity of a manpower;

7) rights to the parcels of land and restriction of the rights.

In addition, the ministry offered the model of the competitive territory of the advancing development including three spheres and phases of development of $\mathrm{TAD}$, namely the kernel is tens hundreds of hectares, the environment consisting of tens of square kilometers and the ecosystem representing completely developed and the functioning territory of the advancing development.

The structure and the constituting TAD developed model not strongly differ from models of the territories of the advancing development of other countries. The main differences consist in conditions, which provide the countries to residents of the territories of the advancing development. The logic is that TAD in the Russian Federation shall provide to residents the best conditions of implementation of activities, within the borders. To achieve the set result conditions of activities of foreign TAD [6-22] were analysed, the received analysis results allowed to constitute table 1 .

Table 1. Conditions of implementation of activities of the foreign territories of the advancing development.

\begin{tabular}{|c|c|c|c|c|}
\hline \multirow{2}{*}{ Country } & \multicolumn{4}{|c|}{$\begin{array}{c}\text { Conditions of implementation of activities } \\
\text { of the advancing development }\end{array}$} \\
\cline { 2 - 5 } & $\begin{array}{c}\text { Income } \\
\text { tax }\end{array}$ & $\begin{array}{c}\text { Wage } \\
\text { tax }\end{array}$ & $\begin{array}{c}\text { Receipt of } \\
\text { the } \\
\text { construction } \\
\text { license }\end{array}$ & $\begin{array}{c}\text { Connection } \\
\text { to system } \\
\text { of power } \\
\text { supply }\end{array}$ \\
\hline $\begin{array}{c}\text { Republic } \\
\text { of Korea }\end{array}$ & $10 \%$ & $8,8 \%$ & 29 days & 28 days \\
\hline USA & $33 \%$ & $7,7 \%$ & 27 days & 68 days \\
\hline China & $15 \%$ & $26,7 \%$ & 67 days & 41 days \\
\hline Japan & $26,4 \%$ & $25,6 \%$ & 193 days & 105 days \\
\hline
\end{tabular}

Having considered conditions of implementation of activities within TAD of Asia-Pacific countries, it is possible to see: in case of development of preference for residents the ministry considered international experience of creation and implementation of activities by the territories of the advancing development and offered the most attractive conditions which consist in the following [6]:

1) $0 \%$ the income tax, on property, on the land for the first 5 years;

2) $0 \%$ import and export customs duties;

3) $0 \%$ of the VAT for import for conversion;

4) $7,6 \%$ of insurance premiums instead of $30 \%$ for the investor the first 10 years;

5) receipt of the land and ready infrastructure is free;
6) the accelerated order of a VAT return of the exporter;

7) there are no checks without consent of the Ministry for the Development of the Russian Far East of the Russian Federation;

8) "one window" for the investor;

9) free customs zone;

10) the simplified state control;

11) the accelerated and facilitated ministerial procedures, including receipt of the construction license, passing of customs.

\section{The investment offers created in the Far East for foreign investors}

The foreign enterprises interested in development of the business outside the states can become interested in the following territories of the advancing development of the Far East provided in table 2.

Table 2. The territories of the advancing development of the Far Eastern Federal District (FEDO).

\begin{tabular}{|c|c|c|}
\hline & $\begin{array}{c}\text { Name and subject } \\
\text { of TAD }\end{array}$ & Specialization of TAD \\
\hline 1 & $\begin{array}{c}\text { TAD } \\
\text { "Nadezhdinskaya" } \\
\text { Primorsky Krai }\end{array}$ & $\begin{array}{l}\text { Light and food industry, } \\
\text { transport and logistic } \\
\text { orientation }\end{array}$ \\
\hline 2 & $\begin{array}{c}\text { TAD } \\
\text { "Komsomolsk" } \\
\text { Khabarovsk Krai }\end{array}$ & Industrial orientation \\
\hline 3 & $\begin{array}{l}\text { TAD "Khabarovsk" } \\
\text { Khabarovsk Krai }\end{array}$ & $\begin{array}{l}\text { Industrial, transport and } \\
\text { logistic orientation }\end{array}$ \\
\hline 4 & $\begin{array}{c}\text { TAD "Beringovsky" } \\
\text { Chukotka } \\
\text { Autonomous Area }\end{array}$ & Mining industry \\
\hline 5 & $\begin{array}{l}\text { TAD "Kangalassa" } \\
\text { Republic of Sakha } \\
\text { (Yakutia) }\end{array}$ & Industrial park \\
\hline 6 & $\begin{array}{c}\text { TAD } \\
\text { "Mikhaylovsky" } \\
\text { Primorsky Krai }\end{array}$ & $\begin{array}{l}\text { Livestock production, } \\
\text { crop production, } \\
\text { production of food }\end{array}$ \\
\hline 7 & $\begin{array}{l}\text { TAD "Kamchatka" } \\
\text { Kamchatka Krai }\end{array}$ & $\begin{array}{l}\text { Tourist and recreational, } \\
\text { port and industrial, } \\
\text { agro-industrial } \\
\text { orientation }\end{array}$ \\
\hline 8 & $\begin{array}{l}\text { TAD "Belogorsk" } \\
\text { Amur region }\end{array}$ & $\begin{array}{l}\text { Agro-industrial } \\
\text { orientation }\end{array}$ \\
\hline 9 & $\begin{array}{l}\text { TAD Priamurye" } \\
\text { Amur region }\end{array}$ & $\begin{array}{l}\text { Industrial, transport and } \\
\text { logistic orientation }\end{array}$ \\
\hline
\end{tabular}

It should be noted that around each of the territories of the advancing development, the area of an economic impact in $1500 \mathrm{~km}$ [23] was designated and the quantity the population, entering it is calculated. Population of the FEFD for January 1, 2015 is given in the table 3 [2]. 
Table 3. Population of the Far Eastern Federal District.

\begin{tabular}{|l|l|}
\hline $\begin{array}{l}\text { The Far Eastern Federal } \\
\text { District }\end{array}$ & $\begin{array}{l}\text { All } \\
\text { population, } \\
\text { man. }\end{array}$ \\
\hline Republic of Sakha (Yakutia) & 956896 \\
\hline Kamchatka Krai & 317269 \\
\hline Primorsky Krai, & 1933308 \\
\hline Khabarovsk Krai & 1338305 \\
\hline Amur region & 809873 \\
\hline Magadan region & 148071 \\
\hline Sakhalin region & 488391 \\
\hline Jewish Autonomous Oblast & 168368 \\
\hline Chukotka Autonomous Area & 50540 \\
\hline Total & $\mathbf{6 2 1 1 0 2 1}$ \\
\hline
\end{tabular}

Based on it, it is possible to draw a conclusion that products and services TAD, which are located in the territory of Primorsky Krai, Khabarovsk Krai, and the Republic of Sakha (Yakutia) will be in the greatest demand. TAD, being in the territory of these subjects, will not be competitors each other as each of them has the specialization influencing products, which are turning out them or services. Here it is necessary to pay attention to proximity of these territories to foreign countries, such neighborhood increases the possible product demand and services issued TAD.

Having chosen one territory of the advancing development by means of developed preferences for their residents, foreign investors including from the Asian countries, can receive certain benefits. For example, in connection with the developed economic situation in the Russian Federation when it is focused on import substitution, competition level considerably decreases; it is profitable to the companies of the Asian countries created within TAD and gives the chance to position the company as the company of the Far East of the Russian Federation. Conditions and selection process of projects and the companies for the territories of the advancing development it is in details stated in the Federal law "About the Territories of the Advancing Social and Economic Development of the Russian Federation" [4], and also on the official site of the Ministry for the Development of the Russian Far East [24], in appropriate section with the list of necessary documentation for assignment of a resident status. Rules and process of assignment of a resident status of TAD are accurately regulated, where as selection criteria of projects of creation of TAD have more flexible nature, and depending on interest of the state in these projects, can change.

Should not forget also about benefits for the Russian Federation, which bear in themselves the territories of the advancing development. First, this attraction of financial resources on development of the Far East of the Russian Federation; secondly, creation of the territories of the advancing development will provide a large number of workplaces for employment of the population that in turn, will give help in fight against unemployment of the population.

\section{Technique of an efficiency evaluation of activities of investment offers in the Far East of the Russian Federation}

It is quite difficult to estimate at the moment efficiency of activities of the territories of the advancing development for the reason that only $3 \mathrm{TAD}$, from planned to 9, are on implementation phase. However, on the basis of the analysis of the projects realized in the Far Eastern Federal District, it is possible to mark out three main criteria by which this assessment is possible:

1) the number of residents of TAD as inflow of financial resources on development and functioning of the Far East depends on the number of the entities which became residents;

2) the proximity of TAD to potential consumers, than is closer this territory to densely populated regions to the developed infrastructure, those the high probability of the product demand and service which are made in the territory of the advancing development;

3) availability of the developed and approved plan of creation and development of the territories of the advancing development, as the main regulating document regulating activities of a certain territory of the advancing development.

Based on the obtained data from the stated above criteria the model of efficiency of activities of the territories of the advancing development provided in the figure 1 was constructed.

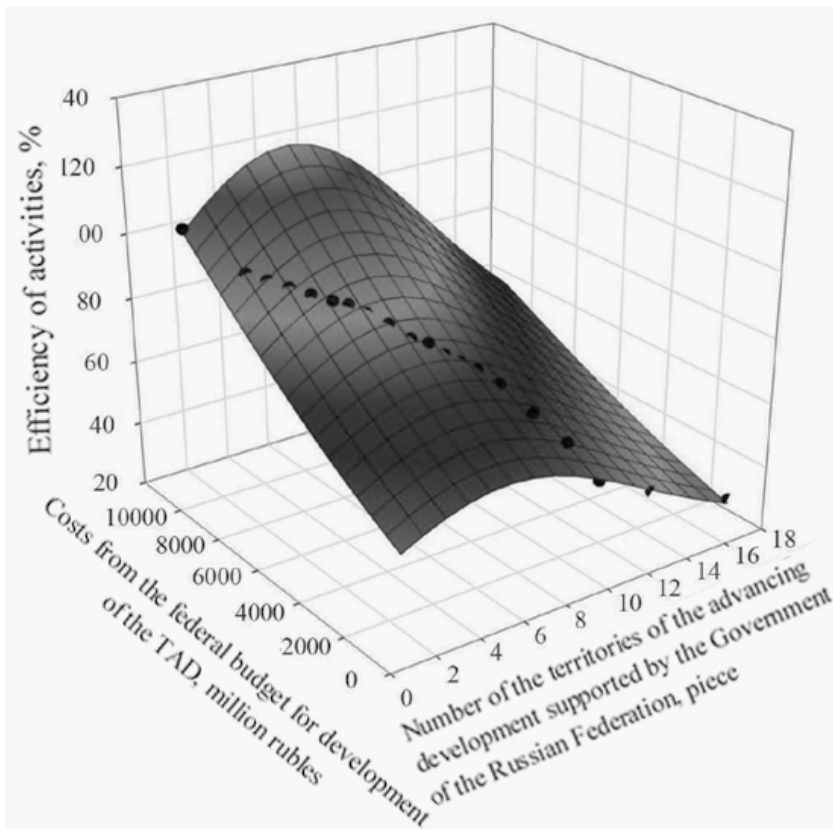

Fig. 1. Model of efficiency of activities of the territory of the advancing development. Three-dimensional regression on Lorenzyan's formula.

As a result of the removed mathematical model of efficiency of the activities of the territories of the 
advancing development provided in the figure 1, authors of article revealed - optimum quantity of TORAHS in the Far East in case of which the maximum performance indicator of their activities is reached, 8 equals.

The result received during the analysis is connected with the fact that on average for development of one TAD from the federal budget by the state spends about 10 billion rubles. The amount of the allocated funds has under itself the following reasons: many kernels of the territories of the advancing development have the destroyed infrastructure which recovery requires big costs from the state that significantly influences quantity of the opened TAD. Achievement of a high rate of efficiency of activities of $\mathrm{TAD}$ requires reducing quantity of costs from the federal budget for their development, by attraction of bigger amount of private financing. However, increase in a share of private investment in TAD is complicated by the fact that there is a lack of the number of residents of the territories of the advancing development. However in case of observance of an optimum ratio of the state and private investments into the territories of the advancing development growth of a performance indicator of their activities to $120 \%$ and more is possible.

The analysis of the received dependences shows that to increase in costs from the federal budget for development of the territories of the advancing development there is a reduction of number of the TAD supported by the government. Owing to what, it is possible to determine necessary costs from the federal budget for development of TAD by the received dependences, depending on their quantity, proceeding from receipt of maximum efficiency of activities by them. Values of costs from the federal budget for development of the TAD, depending on quantity supported by the government of TAD are approximated in expressions:

$$
\begin{aligned}
\mathrm{E}_{4-6} & =\frac{513}{\left[1+\left(\frac{N-4,8}{0,65}\right)^{2}\right] \cdot\left[1+\left(\frac{C-4043,8}{2316,31}\right)^{2}\right]}, \delta=7 \% ; \\
\mathrm{E}_{8} & =\frac{549}{\left[1+\left(\frac{N-122}{25,3}\right)^{2}\right] \cdot\left[1+\left(\frac{C-5520}{5985,4}\right)^{2}\right]}, \delta=6 \% ; \\
\mathrm{E}_{10-13}=\frac{1129}{\left.\left[\frac{N-5,822}{0,89}\right)^{2}\right] \cdot\left[1+\left(\frac{C-11935}{8328}\right)^{2}\right]}, & \delta=5 \% ; \\
\mathrm{E}_{20} & =\frac{1575}{\left[1+\left(\frac{N-5,157}{1,13}\right)^{2}\right] \cdot\left[1+\left(\frac{C-16203,6}{13274,5}\right)^{2}\right]}, \delta=1 \% .
\end{aligned}
$$

$\mathrm{E}_{\mathrm{i}}$ - efficiency of activities $\mathrm{i}$ - the territories of the advancing development, $\% ; \mathrm{N}$ - number of the territories of the advancing development supported by the government, piece; $\mathrm{C}$ - costs from the federal budget for development of the territories of the advancing development, million rubles; $\delta$ - a relative error between the calculated values and dependences received as a result of an experiment on the basis of the analysis of the international experience of implementation of the territories of the advancing development [25-29].

For establishment of statistical certainty of the received regression equations Fischer's criterion was used. Use of this criterion assumes calculation settlement the statistician and their comparison with analytical values. The received regression equations are considered as values if calculated values the statistician of criterion of Fischer is less than corresponding values received in practice.

When checking the equations, in all cases calculated values turned out slightly less analytical. Therefore, these equations can be considered statistically significant, and they can be used for determination of efficiency of activities of the territories of the advancing development.

Besides, for the analysis of expressions relative errors of $\delta$ between calculated values, determined with use of the received regression equations and the dependences received in the analytical way were calculated. The maximum value of the calculated relative errors does not exceed $7 \%$ that speaks about rather high precision of the received dependences.

\section{Conclusion}

1. Results of the conducted research showed that development of the Far East including innovative, goes unevenly, is not present single "engine" which would be aimed at the complex development of the region.

2. One of the ways of complex development of the region initiated by the state is creation of the territories advancing development. In the territories of the advancing development based on the large enterprises and associations interested in receipt of the status of residents, the Government of the Russian Federation sees "engine" of the region.

3. Residents of TAD shall receive the foreign investments necessary for successful implementation of their activities; the developed economic situation in the Pacific Rim will only promote this process.

4. Participants of a working group on forming of strategy of innovative development are sure of prospects of development of the territories of the advancing development, that conditions of implementation of activities on TAD similar to the Russian conditions do not exist.

5. Russia wins first place on the area among the countries of the world, uniform development of regions of which requires fixed costs from the federal budget. The developed mathematical model shows at what moment of costs from the federal budget for development of TAD can be reduced or suspended. 
6. For assessment efficiency of activities of the territories of the advancing development, in FEFU the mathematical model that showed was developed that the optimum quantity of the territories of the advancing development equals the 8th, their bigger quantity will reduce efficiency. In addition, it revealed the need for development of other mathematical models directed to reasons for number of the entities necessary for a program implementation of development of the region. The mathematical model of efficiency of activities of TAD was developed for unique conditions of the Russian Federation.

Successful implementation of the concept of creation of the territories of the advancing development consists in carrying out the profound analysis of foreign experience which results could be used during creation of TAD of the Far East, taking into account special conditions of the region.

7. Analyzing the international experience of creation of the territories of the advancing development, it is possible to tell: the model of the territory of the advancing development created in Russia on the basis of the Federal law "About the Territories of the Advancing Social and Economic Development in the Russian Federation" and taking into account the revealed criteria and features will provide competitive conditions of investment that will favorably affect the investment climate of the country, and the preferential mode of activities, will promote effective use of limited resources and rapid economic growth.

\section{References}

1. About results of presidency of Russia in APEC. Institute of world economy and international relations of name E.M. Primakova of the Russian Academy of Sciences. http://www.imemo.ru/files/File/ru/conf /2013/30012013_KADtez.pdf

2. Federal State Statistics Service. http://www.gks.ru/

3. G.I. Abdrakhmanova, L.M. Gokhberg, K.A. Ditkovsky, E.A. Islankina, Rating of innovative development of subjects of the Russian Federation, 4 (2016)

4. About the territories of the advancing social and economic development in the Russian Federation: the federal law of the Russian Federation of December 29, 2014, no. 473-FL (2014)

5. Putin: the cooperation with Asia-Pacific countries is priority for Russia. Politikus News agency. http://politikus.ru/events/ 35195-putinsotrudnichestvo-so-stranami-atr-prioritetno-dlyarossii.html

6. About results of activities of the Ministry of the Russian Federation of development of the Far East in 2013 and the first half of 2014. The Ministry of the Russian Federation of development of the Far East. http://minvostokrazvitia.ru/upload/kollegiyaDV.pdf

7. G. Dominguez, Deutsche Welle (2015)

8. L. Rubini, M. Di Tommaso, E. Barbieri, International Encyclopedia of the Social \& Behavioral Sciences, 2, 207 (2015)

9. Y. Li, Z. Zhang, Social and Behavioral Sciences, 96, 182 (2013)

10. Z. Min, M. Lijun, Z. Bo, Y. Zhihong, Journal of Corporate Finance, 36, 15 (2016)

11. L. Qing, L. Yi, Journal of International Economics, 97, 392 (2015)

12. T. Fishman, H. Schandl, H. Tanikawa, Ecological Economics, 113, 76 (2015)

13. W. Yu, Social Science Research, 39(6), 1088 (2010)

14. J. DeBacker, B. Heim, A. Tran, Journal of Financial Economics, 117(1), 122 (2015)

15. G. Squires, S. Hall, Land Use Policy, 33, 81 (2013)

16. J. Ham, C. Swenson, Journal of Public Economics, 95, 779 (2011)

17. L. Reynolds, S. Rohlin, Journal of Urban Economics, 88, 1 (2015)

18. B. Park, Political Geography, 24(7), 850 (2005)

19. H. Park, E. Rene, S. Choi, A. Chiu, Journal of Environmental Management, 87, 1 (2008)

20. J. Kim, Journal of Asian Economics, 16(6), 973 (2005)

21. K. Kim, E. Kim, Habitat International, 29(2), 183 (2005)

22. Y. Lim, Journal of Banking \& Finance, 35(2), 456 (2011)

23. About approval of the Concept of investment development Tomsk till 2025 (with the forecast till 2030). Administration of the region of the Tomsk region.http://www.investintomsk.com/files/doc/rato ot_29_12_2014_957ra_koncepciya_invest_razvitiya_to.pdf

24. The territories of the advancing social and economic development. http://minvostokrazvitia.ru/

25. J. Wang, Journal of Development Economics, 101(2), 133 (2013)

26. M. Levien, Development and Change, 44(2), 381 (2013)

27. C. Long, X. Zhang, Journal of International Economics, 84(12), 112 (2011)

28. M. Levien, Journal of Peasant Studies, 39(3-4), 933 (2012)

29. D.B. Solovev, International Journal of Electrical Power and Energy Systems, 73, 107 (2015). http://dx.doi.org/ 10.1016/j.ijepes.2015.04.011. 